\author{
JOSÉ MARÍA SÁNCHEZ \\ MARÍA DOLORES QUIÑONES \\ UNIVERSIDAD DE SEVILLA
}

\title{
Materiales pictóricos enviados a América en el siglo XVI
}

A LO LARGO DEL SIGLO XVI, el paso de pobladores desde Sevilla a América fue continuo y creciente, como lo testimonian los registros de las flotas que hicieron ese recorrido a lo largo de toda la centuria. Naturalmente, como parte de ese contingente humano hubo numerosos artesanos y artistas.

Pintores y canteros fueron profesionales imprescindibles durante los años iniciales de ocupación del territorio americano: los pintores formaban parte de las expediciones de descubrimiento y conquista que elaboraban la cartografía de las nuevas tierras y los canteros construían los primeros edificios eclesiásticos y civiles de fábrica que se levantaron en las nacientes ciudades.

Posteriormente, una vez establecida una importante población "de asiento", fue necesario abastecerla de todo tipo de bienes de consumo. En un principio, ello se hizo mediante el envío de mercancías desde España, pero a medida que las urbes crecieron, tal solución resultó insuficiente y se advirtió la necesidad de generarlas localmente. Tales ciudades serían los puntos de destino de cientos de artesanos y artistas peninsulares que se aventuraron a cruzar el Atlántico en busca de un mercado y una clientela en expansión.

Entre los colectivos más importantes presentes en el Nuevo Mundo cabe destacar el de los plateros, pues, al fin y al cabo, uno de los grandes atractivos de los territorios americanos fue, en principio, su riqueza metalúrgica, aunque también sobresalieron escultores, loceros y bordadores, entre otros, que fueron llegando a América más esporádicamente, casi siempre de acuerdo con sus circunstancias personales o con la demanda de sus productos en los distintos virreinatos. 


\section{JOSÉ MARÍA SÁNCHEZ Y MARÍA DOLORES QUIÑONES}

El siglo Xvi fue, desde un punto de vista cuantitativo, la centuria en que se produjo la mayor emigración de artistas desde España hacia América, cantidad que, en los siglos posteriores disminuyó de manera progresiva a causa, principalmente, de la actividad de los nuevos talleres criollos, ya provistos de mano de obra indígena.

Pronto los artistas instalados en América tuvieron necesidad de importar desde la península ciertos materiales o instrumentos imprescindibles para sus oficios. Su demanda se concentró fundamentalmente en aquellos que era difícil obtener en los territorios de ultramar, que no podían ser sustituidos por productos similares de la tierra o, simplemente, que imprimían en sus obras una impronta metropolitana.

Todas las mercancías que demandó el mercado americano se expidieron por las vías del comercio regular, es decir, a través de las dos flotas que anualmente partían de los muelles de Sevilla y, por ello, su volumen y naturaleza han quedado constatadas en los registros de los cargamentos que, con fines fiscales,

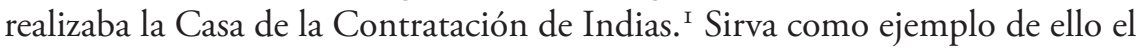
siguiente documento de I592:

Registró Juan de Bustinza, vecino de la ciudad de Sevilla, en la nao que Nuestro Señor salve nombrada Nuestra Señora del Rosario, de que es maestre Cristóbal Cuello, que va a la provincia de Nueva España este presente año de I592 en conserva de la flota de que va por general Marcos de Aramburu, las mercaderías que abajo irán declaradas, las cuales van consignadas a Juan de Tolosa, vecino de México, y, por su ausencia, a quien su poder tuviere, y van por su cuenta y riesgo, porque son suyas y le pertenecen, $y$ van marcadas con la marca de fuera y son las siguientes:

Un cofre de hierro núm. 8 con lo siguiente:

- 50 libras de albayalde a 24 reales arroba, I 632 maravedíes.

- 2 arrobas de azarcón a 26 reales arroba, I 768 maravedíes.

- 78 libras de esmaltes y cenizas de esmaltes para pintores a 4 reales la libra, Io 608 maravedíes.

-20 gruesas de pinceles para pintores a 3 reales gruesa, 2040 maravedíes.

I. La base documental del presente trabajo la constituyen los "Registros de embarcaciones: ida" conservados en la Sección III, Contratación, del Archivo General de Indias, entre las fechas extremas de I 492 y I600. Esta serie incluye un total de 54 legajos, catalogados, que van de I 079 a I I 33. No se trata de un conjunto completo, pues falta un considerable volumen de legajos pertenecientes a los tres primeros cuartos del siglo, y la serie sólo manifiesta regularidad a partir de 1583 . 
—ítem, por el cofre en que va lo dicho 400 reales, I3 600 maravedíes.

Total 29648 maravedíes.

En 7 de diciembre de 1592 montan los derechos del Almojarifazgo de las Indias de lo contenido en este registro I 482 maravedíes, por los cuales se obligó en partida de 740523 maravedíes.

Pagó de avería 592 maravedíes en 7 de enero de 1593.

De Lonja 908 maravedíes. ${ }^{2}$

Los envíos de materiales artísticos fueron comunes a todos los oficios, pues tanto pintores como escultores o plateros, pasando por alfareros y bordadores, entre otros, los requerían. En I595, Esteban Pérez, vecino de la ciudad de Sevilla, registraba en el navío San Rafael, con destino a la provincia de la Nueva España, "un barril medio quintaleño, sin número, en que va dentro ioo libras de piedra azul para los que labran loza. Costó a real la libra, montan 3400 maravedíes". ${ }^{3}$

Generalmente, esos productos cruzaron el océano remitidos por los "cargadores de Indias", comerciantes que, conociendo las demandas del mercado americano, consignaban todo tipo de productos de los que se podía obtener algún beneficio. No se trató, pues, de un comercio especializado y, en ese sentido, los materiales artísticos formaron parte indiferenciada de los cargamentos de los barcos y se registraron al lado de todo tipo de productos de la más variada índole.

Sólo en alguna ocasión, muy excepcionalmente, el envío de ciertos materiales obedeció a encargos precisos de artistas que los necesitaban para crear obras concretas. Puede ilustrar este hecho la carta que en 1596 dirigía Gaspar Encinas, locero asentado en Puebla de los Ángeles, a su mujer, María Gaitán, residente en Triana, en estos términos: "Y mirad que, como os aviso en las demás [cartas], de los mejores colores que hubiere azul, verde, con los demás y el libro de ellas también, porque tengo cierta cantidad de azulejos que hacer, me traed, y un par de aderezos de espadas y dagas muy buenas". ${ }^{4}$

En el caso particular de los pintores, éstos hicieron traer de Espańa todo lo necesario para desarrollar su arte: pinceles, colores (pigmentos), aceites, barni-

2. Archivo General de Indias (en adelante AGI), Contratación, I I04, año I592-I593, núm. 7-I, f. II $8 \mathrm{r}$.

3. AGI, Contratación, IIII3, año I595, núm. 8, f. 65 r.

4. Enrique Otte, Cartas privadas de emigrantes a Indias, I540-1616, Cáceres, Consejería de Cultura de la Junta de Andalucía/Escuela de Estudios Hispanoamericanos, I998, p. I70. 


\section{JOSÉ MARÍA SÁNCHEZ Y MARÍA DOLORES QUIÑONES}

ces y soportes (lienzos) para realizar sus obras, además de bol y panes de oro y plata para los dorados y estofados de las obras de imaginería policroma. ${ }^{5}$

Respecto a los pinceles, en el mercado sevillano del quinientos había una gran variedad de ellos, distintos por su tamaño — brochas, trinchetas y pinceles_-, su grosor — bastos o finos_- el corte de sus cerdas — planos o de punta - y por el material de sus hebras — hilos de seda o pelo de cabra, ardilla, turón, meloncillo o vero (la famosa marta cebellina)—, que se empleaban según ciertas técnicas o propósitos específicos. ${ }^{6}$ Tales diferencias, sin embargo, no son explícitas en la documentación, y posiblemente sólo eran objeto de comercio los pinceles cuyas cerdas no podían encontrarse en los territorios americanos.

Habitualmente, los pinceles se fabricaban en los talleres, pues su elaboración era sencilla, ya que consistía simplemente en atar con fuerza las cerdas o pelos e introducirlos en un cañón de pluma de ave u hojalata al que se dotaba de un mango de madera resistente y de poco peso — pino o peral, preferentemente. No obstante, también se podían comprar ya manufacturados.

En la segunda mitad del siglo Xvi, comprobamos que a Nueva España se expedían tanto cañones y cerdas sueltas como pinceles completos.

En I594, Hernando de Zumalburu cargó en la nao San Buenaventura, entre otros productos, "dos millares de cañones de cisne a 36 reales, 2448 maravedíes"; 7 años después, en I596, Pedro Colbet, vecino de la ciudad de Sevilla, registraba en la nao La Paloma Blanca: " 7 libras de cerdas comunes para pintores a 2 reales la libra, 476 maravedíes". ${ }^{8}$

5. Sobre los procedimientos y materiales pictóricos usados en España durante el siglo Xvı, pueden consultarse: Francisco Pacheco, El arte de la pintura, Madrid, Cátedra, I990; Rocío Bruquetas Galán, "Los procedimientos y los materiales pictóricos en la corte de Felipe II”, en IX Jornadas de Historia del Arte. El arte en las cortes de Carlos Vy Felipe II, Madrid, Consejo Superior de Investigaciones Científicas, 1999, pp. 31 I-319; y Técnicas y materiales de la pintura española en los Siglos de Oro, Madrid, Fundación Telefónica, 2002.

6. Así lo testimonia Pacheco: "que los pinceles para pintar los azules sean suaves y de punta, grandes y pequeños"; en otro momento, el mismo autor añade: "últimamente, las brochas, trinchetas y pinceles que se usan en el temple son de ordinario de sedas, como las escobillas, de que hacen grandes y pequeños, y, por maravilla, se usa de pinceles de punta, si no fuese para ojos y bocas, o cosas sutiles. Los más ásperos se acomodan mejor en la pintura de los lienzos; los más blandos, sobre tablas y sobre parel, donde podrán servir los de cabra, de pexe, o de meloncillo y algunos de punta" (op. cit., pp. 452 y 486-487).

7. AGI, Contratación, I IO6, año I594, núm. 3-I, f. 243r. y v.

8. AGI, Contratación, II23, año I596, núm. 3-I, f. 54r. y v. 
Los pinceles completos se comercializaron por docenas o gruesas - I2 docenas- y su precio osciló alrededor de tres maravedíes la unidad. Sirva como ejemplo de ello el registro efectuado por Juan de Bustinza en I 592 en la nao Nuestra Señora del Rosario: "20 gruesas de pinceles para pintores a 3 reales la gruesa”, con destino a México.

El procedimiento de la pintura al óleo fue, sin duda, el predominante en los territorios de ultramar durante el siglo XVI, aunque también continuó vigente durante varias décadas la técnica medieval del temple.

En el óleo los pigmentos van aglutinados con aceite, sustancia que actúa como vehículo y brinda protección y viveza. Los aceites empleados durante el siglo Xvi fueron siempre de origen vegetal, tales como los de linaza, nueces, espliego o alhucema, a lo que se añadía, para acelerar el proceso de secado, algún producto como vidrio molido o litargirio. ${ }^{9}$

El aceite más usado fue, sin lugar a dudas, el de linaza, por ser el más claro, fluido, secante y, al mismo tiempo, resistente. A estas propiedades "plásticas" se podría añadir una ventaja más: podía almacenarse indefinidamente, ya que no perdía sus propiedades con el paso del tiempo - lo cual, por ejemplo, no ocurría con el de nueces, que era preciso usar "fresco" y recién fabricado. Sin embargo, como inconveniente tendía a amarillear y, con el paso del tiempo, perdía elasticidad, lo cual implicaba riesgos de cuarteaduras.

Su uso debió ser frecuente en América, como lo prueba su presencia continua en los cargamentos de los barcos y su invariable comercialización en botijas de arroba o media arroba, es decir, en grandes cantidades debido a su bajo precio, que osciló entre 22 y 25 reales la arroba (34 maravedíes la libra). Ello lo ilustra el envío realizado en 1592 por Juan Lorenzo, vecino de Sevilla, en la nao San Juan Bautista, donde registró con destino a la Nueva España " 3 arrobas de aceite de linaza a 22 reales, 2244 maravedíes". ${ }^{\text {I }}$

Menos frecuentes fueron en las flotas otros aceites vegetales, a pesar de las indudables ventajas de algunos de ellos, ${ }^{\text {II }}$ lo cual se debe a que, al resultar mucho más caros, el margen de beneficio para el cargador podía ser escaso. Véase como ejemplo el envío de productos artísticos que realizó Andrés Tori-

9. Aceite de linaza cocido con un poco de almagarta.

IO. AGI, Contratación, I IO2, año I592, núm. 2-I, f. 88r. y v.

I I. El de nueces se empleó frecuentemente porque no amarilleaba, lo cual lo volvía idóneo para los blancos y los azules, pues no modificaba la naturaleza de los pigmentos. 
bio en 1594 en la nao Nuestra Seńora del Rosario con destino al puerto de San Juan de Ulúa de la Nueva España:

Caja núm. 9

- Primeramente, una caja pequeńa con Ioo docenas de panes de plata batida a 7 reales docena, montan 23800 maravedíes.

-ítem, 8 docenas de pinceles de pintor a real la docena, monta 272 maravedíes.

Cajón núm. 4

—ítem, un cajón tosco con 9 frascos de hoja de Milán, los 8 de aceite de almendras dulces y de ajonjolí y de mata, que llevan 70 libras en todos de aceites, que monta todo I 40 reales, 4760 maravedíes.

-ítem, otro frasco con 9 libras de aceite de linaza a real libra, monta 306 maravedíes.

Cajón núm. 6

-ítem, un cajón tosco con 6 botijas que llevan 2 arrobas y 5 libras de aceite de linaza a 25 reales el arroba que monta I 870 maravedíes.

Barril núm. 8

—ítem, un barril quintaleńo con I2 arrobas y media de barniz a 6 ducados el arroba, monta 5620 maravedíes. ${ }^{12}$

También se remitió desde Sevilla a América una gran variedad de pigmentos, a pesar de la abundancia de colores que ya usaban los indios antes de la llegada de los españoles, tal y como lo testimonian las crónicas del momento. Hernán Cortés, en I520, se admiró ante la variedad de pigmentos que se comerciaban en el mercado de la ciudad de Temixtitlan, y sobre ello comenta: "venden colores para pintores, cuantos pueden hallar en España y de tan excelentes matices cuanto pueden ser". ${ }^{13}$ El mismo Colón, tras su segundo viaje, advertía a los reyes de la existencia de abundantes minas de azul fino en La Española. ${ }^{14}$

I2. AGI, Contratación, II Io, año I594, núm. I4-I, f. 38r. y v.

13. Hernán Cortés, Cartas de relación a Carlos V, Madrid, Cambio I6, 1985, p. 59 (cit. por Bruquetas Galán, Técnicas y materiales..., op. cit., p. I25).

I4. Algunas décadas después, en I579, Felipe II ordenaba a sus oficiales de la isla que, en la primera flota que partiera hacia España, le remitiesen "dos cargas del mineral azul en piedra [...] que sea de lo mejor y más perfecto que se pudiere hallar" para cosas de su servicio (AGI, Santo Domingo, 868, lib. 3, ff. 90v. y 9rr., cit. por Bruquetas Galán, Técnicas y materiales..., op. cit., p. I24). 
En vista de ello, la intensa comercialización de pigmentos podría haberse debido al desconocimiento de nuestros pintores respecto de la elaboración y el tratamiento de materiales autóctonos o, simplemente, a la predilección por los materiales artísticos que conocían de España y que podían dar a sus obras una impronta metropolitana.

No obstante, su uso también debió estar condicionado por la preferencia de los clientes que creían garantizar con ellos la calidad de sus obras. Así lo insinúa, por ejemplo, el contrato para dorar el retablo de la Virgen del Convento de la Merced de Cuzco en 158I, donde los monjes requirieron a sus autores "colores finos de Castilla". ${ }^{\text {Is }}$

Habitualmente, los pigmentos se refieren en los documentos como "colores para pintores", aunque se usaban tanto en pinturas como en labores de policromado y estofado de esculturas y retablos.

Las referencias son muy variadas en los registros de los navíos. Así, en I592, Martín de Salazar cargó en la nao San Pedro, con destino al puerto de Cartagena, "una espuerta con colores de pintor que costaron Ioo reales ", ${ }^{16}$ y Margarita Enríquez Erbaut, vecina de Sevilla, envió en I594, en la nao Santa María de la Concepción, entre otros productos, dos barriles quintaleños, con los números I2 y I3, cada uno con "I9I libras de colores de pintores, de todos colores surtidos, a I60 maravedíes la libra, 32470 maravedíes". ${ }^{17}$

En otras ocasiones, los registros son más explícitos y señalan con precisión todos y cada uno de los pigmentos, las cantidades enviadas y sus correspondientes precios. Antonio Hurtado Salguero, mercader peruano, embarcó en la nao Santa Catalina, con destino al puerto de Nombre de Dios en 1592, dos cajas que contenían lo siguiente:

Caja núm. 4I3:

- 4 docenas de escribanías finas a 36 reales, 496 maravedíes;

- 6 dichas comunes a 20 reales docena, 4080 maravedíes;

- 3 libras de ceniza azul para pintores a 34 reales la libra, 3468 maravedíes;

- 3 libras dichas segunda a 28 reales, 2856 maravedíes;

— 5 libras de verde terre a 22 reales, 3740 maravedíes;

I5. Jorge Cornejo Bouroncle, Derroteros de arte cuzqueño; datos para una historia del arte en el Perú, Cuzco, Inca, 1960, p. I63.

I6. AGI, Contratación, I096, año I592, núm. 2, ff. I40r. y I4Ir.

I7. AGI, Contratación, I II I, año I594, núm. Io-III, f. 2 I-2Iv. Envío realmente cuantioso que equivale a $176 \mathrm{~kg}$. 


\section{JOSÉ MARÍA SÁNCHEZ Y MARÍA DOLORES QUIÑONES}

-7 libras de esmaltes a 8 reales libra, I 904 maravedíes;

-6 libras de azarcón a I.5 reales la libra, 306 maravedíes;

-6 libras de jenuli fino a 6 reales libra, I 224 maravedíes;

- I.5 libras de verde granillo a 22 reales, I I 22 maravedíes;

— I libra de espalto a 50 reales, I 700 maravedíes;

-6 libras de sombra del Ticiano a 3 reales, 6I 2 maravedíes;

-4 libras de sombra negra del Ticiano a 5 reales, 680 maravedíes;

-2 libras de urchilla a 4 reales, 272 maravedíes;

— I3 sombreros de niños de colores a 4 reales, I 768 maravedíes;

— I caja I 2 reales, 408 maravedíes;

- 4 varas de arpillera a 60 maravedíes, 360 maravedíes;

Caja núm. 276:

— Ioo libras de bol para pintores en 44 reales, I 496 maravedíes. ${ }^{18}$

Los pigmentos se mandaron procesados, es decir, ya sometidos a una transformación más o menos básica de depuración. Así parece deducirse que, en ocasiones, aparecen calificados como "finos" o "de segunda", ${ }^{19}$ adjetivos que hacen referencia a las distintas calidades posibles tanto en su gama cromática como en la molienda, más o menos delicada, del grano. ${ }^{20}$

Aunque algunos de los pigmentos más usados en España se importaban desde Italia y Flandes —en particular de Venecia y Amberes, los centros productores europeos más especializados en materiales pictóricos— ${ }^{2 \mathrm{I}}$ ello no se hace constar en los registros de los envíos a ultramar.

La gama de colores existentes en el taller de un pintor era bastante amplia y variada. Francisco Pacheco, en El arte de la pintura, comenta al respecto:

los colores, ya se ha visto, que han de ser los mejores, más finos, delgados y subidos: lindo albayalde de Venecia, bermellón famoso, jenuli alegre y azarcón en grano, azules de cenizas finas y delgadas, verdes montaña y terra sutiles; fina encorça, buenos

I8. AGI, Contratación, I097, año I592, núm. 5-I, ff. 222 r.-227 r.

19. La expresión "color fino" podría ser sinónimo de gran pureza y calidad, es decir, que remitiría a los mejores tonos disponibles en el mercado.

20. En los talleres los pigmentos se trituraban y se molían con agua en la losa o se mezclaban con óleo, es decir, se refinaban. Tal es el caso de la azurita, pigmento mineral azul, para cuya obtención debía lavarse con vinagre.

2I. Así el famoso albayalde veneciano, el carmín de Florencia-Venecia o el esmalte y negro de Flandes... 
ocres, sombra de Italia y negro de carbón y, si fuere menester, almagre de Levante, todo muy molido; lindo granillo para ayudar a los verdes; añil y orchilla para oscurecer los azules; el carmín será mejor de Florencia y la mezcla de la goma con él será flaca y en el azul algo más fuerte. ${ }^{22}$

De todos ellos, los remitidos a América a lo largo del siglo XVI fueron los siguientes:

\section{Gama de blancos}

El pigmento blanco más importante en el siglo xvi fue el albayalde (del árabe al-bayad, blanco), también llamado "blanco de plomo o cerusa". ${ }^{23}$ Se obtenía mediante un proceso relativamente sencillo, consistente en exponer finas láminas de plomo a vapores de vinagre fuerte para producir así, en su superficie, una oxidación que, raspada y secada al sol, constituía el pigmento. ${ }^{24} \mathrm{~A}$ pesar de ello, rara vez se producía en los talleres de los pintores, porque era muy venenoso y resultaba extraordinariamente peligroso manejarlo; por ello solía importarse desde Italia o se compraba ya fabricado en boticas.

Era un blanco muy opaco, de un gran poder cubriente, y se le consideraba uno de los tonos básicos de la pintura porque "ayuda a todas las colores" al facilitar su secado. Sin embargo, junto a estas incuestionables ventajas, el albayalde presentaba un serio inconveniente: su tendencia a amarillear, sobre todo si se secaba en la oscuridad o en ambientes húmedos, lo cual podía paliarse con un barniz superficial.

Los envíos de albayalde fueron muy frecuentes y en grandes cantidades, pues, además de usarse como color blanco, se empleó como imprimación, es decir, como preparación previa de la superficie del soporte. Por eso, en I557, por ejemplo, el pintor Pedro de Villegas, vecino de la ciudad de Sevilla, realizó a Honduras, en la nao Los Tres Reyes Magos, el envío de "una arroba de albayalde". ${ }^{25}$

22. Pacheco, op. cit., p. 454.

23. Ya se conocía en la Antigüedad clásica, cuando las hetairas griegas lo utilizaban, mezclado con miel, para producir mascarillas que "blanquearan" sus rostros y pomadas que curaran infecciones.

24. El procedimiento, bien conocido, es descrito por autores clásicos como Plinio, Teofastro o Vitrubio y por autores del siglo xvi como Bernardo Pérez de Vargas o Pacheco.

25. AGI, Contratación, I079, año I557, f. 872 r. y v. 


\section{JOSÉ MARÍA SÁNCHEZ Y MARÍA DOLORES QUIÑONES}

Habitualmente, debió comercializarse en forma de escamitas o lascas blancas que se desprendían de las láminas de plomo, y entonces su precio oscilaría en torno a los 45 maravedíes la libra; pero también se llegó a vender labrado, es decir, purificado mediante sucesivos lavados, finamente molido al agua y compactado en forma de panecillos, y su precio ascendía entonces hasta los 136 maravedíes la libra. De ambas maneras aparece en el envío que Jerónimo Gutiérrez, vecino de Sevilla, realizó en la nao Buena Esperanza en I594: "2 libras de albayalde labrado 8 reales, 272 maravedíes; una libra de cardenillo, pesa ocho libras $[s i c]$ a 4 reales, I 088 maravedíes; 2 arrobas de albayalde por 2 ducados, 374 maravedíes". ${ }^{26}$

En Perú, su empleo se verifica documentalmente a finales del siglo Xvi en los libros reales de cobros de alcabalas, donde se consigna en varias ocasiones "albayalde de Sevilla" entre las mercancías por aforar. ${ }^{27}$

\section{Gama de verdes}

En los registros de mercancías es frecuente encontrar la expresión "verde para pintores", ${ }^{28}$ de forma genérica, aunque también se nombran pigmentos como el cardenillo, el verde terre y el verde granillo.

El cardenillo, también llamado "verdigrís" o "verdete", era un pigmento de color verde azulado, muy intenso, aunque con bajo poder cubriente, por lo que se utilizó a menudo para producir efectos de veladuras mezclado con aceite o barniz, y por ello fue el favorito de los pintores flamencos y venecianos. Era apto para todas las técnicas, con excepción del fresco. ${ }^{29}$

Se producía mediante oxidación de planchas de cobre colocadas en un recipiente con vinagre durante is días a temperatura templada, con lo cual se

26. AGI, Contratación, II Io, año I594, núm. 5-II, f. 8r. y v.

27. Libro real donde se asientan los pesos de plata que se cobran de las alcabalas reales, Cajas Reales, 63, años 1597-I625, f. s/n; cit. por Gabriela Siracusano, El poder de los colores, Buenos Aires, Fondo de Cultura Económica de Argentina, 2005, p. 47.

28. El mercader Lionel de Cuadro, afincado en Sevilla, registró en 1597, en el navío La Salvadora que partía con destino a Nueva España: "veinte y siete libras de verde para pintores en tres barrilillos y dos saquillos a cinco reales la libra, 6290 maravedíes” (AGI, Contratación, I I23, año I597, núm. 2-I, f. 83 r. y v.).

29. Fue muy utilizado desde la Antigüedad clásica y Pedacio Dioscórides (siglo I d.C.) lo refiere en su tratado "De materia médica". 
formaba una capa de corrosión homogénea que, raspada, constituía el pigmento. $^{30}$

Como inconveniente cabría señalar su difícil aplicación, pues se ennegrecía con la humedad y era tóxico. Pacheco comenta su uso en pintura al óleo en el siguiente párrafo:

Los verdes labran algunos con blanco y negro a olio y después lo bañan con cardenillo molido con aceite de linaza; suélese para esto purificar moliéndolo primero en la agua con vinagre y unas hojas o cohollos de ruda, colado por tela de cedazo, y después de seco, molido como se ha dicho a olio, y suelen, después de bañado la primera vez, volverlo a oscurecer y tornarlo a bańar echándole un poco de barniz, y queda muy lucido. ${ }^{31}$

Se documenta su envío a América, por ejemplo, en el registro realizado en 1594 por Alonso de Rueda en la nao San Salvador, expedida con destino a Nueva España:

- 3 libras y 2 dozavos de almojatre a 7 reales la libra, 73 I maravedíes;

- 3 libras y 4 dozavos de cardenillo que vale a 6 reales la libra, 653 maravedíes;

-5 onzas y cuarta de esmalte rojo a 8 reales la onza, vale I 428 maravedíes. ${ }^{32}$

Como se puede advertir, fue un pigmento barato, pues su precio osciló en torno a los 6 reales la libra.

Mucho más caro era el "verde terre", también llamado "tierra verde" o "verdacho", 33 pigmento natural muy estable, de color verde oscuro y apto para todas las técnicas pictóricas. Posiblemente también se le nombró "verde granillo", denominación que parece hacer referencia simplemente a su textura granulosa, pues se comercializa al mismo precio, en torno a los 22 reales la libra, es decir, a 748 maravedíes. ${ }^{34}$

30. Así pues, sus ingredientes eran básicamente dos: el cobre y el vinagre, aunque en distintos tratados también se señalan como tales la orina y la sal amónica. En todos los casos, el pigmento se obtenía gracias al efecto corrosivo de esas sustancias sobre el cobre.

31. Pacheco, op. cit., p. 484.

32. AGI, Contratación, i IIo, año I594, núm. i I, f. 25 r. y v.

33. Del italiano verdaccio. La más famosa tierra verde fue la terra de Verona.

34. Antonio Hurtado Salguero, pasajero de la nao Santa Catalina, llevó consigo en 1592 a la 
56 JOSÉ MARÍA SÁNCHEZ Y MARÍA DOLORES QUIÑONES

\section{Gama de rojos}

Los pigmentos rojos fueron los más solicitados, y el mercado español contaba con una amplia variedad de ellos: el bermellón, el almagre, el bol, el azarcón y el carmín. Ciertamente, su uso fue muy frecuente, sobre todo para pintar ropajes y producir encarnaciones en la policromía de las imágenes.

El rojo más demandado por los talleres de ultramar fue el bermellón, pigmento bastante duradero, muy opaco y denso. Conocido ya por los egipcios, se obtenía de manera natural de la molienda del cinabrio, mineral de color rojo púrpura, aunque en el siglo Xvi también se fabricó artificialmente al espolvorear mercurio sobre azufre fundido.

Su envío a la Nueva España está bien documentado en la segunda mitad del siglo XVI, como lo ejemplifica Nicolás Lambartengo, quien registró en el navío La Magdalena, en I592:

Una caja perulera núm. 26 con:

- I2 docenas de espejos cuartos de diez a 25 reales, Io 200 maravedíes;

$\rightarrow$ docenas chicos sotocuartos a I6 reales, 4896 maravedíes;

-2 gomas de agujas capoteras a 20 reales, I 360 maravedíes;

-7 fieltros ordinarios a 70 reales, I6 660 maravedíes;

- I gruesa y 2 docenas de papeles de estampas a I 2 reales la gruesa, 476 maravedíes y

-7 libras de bermellón a 4 reales, 952 maravedíes. ${ }^{35}$

Un año después, en I593, Francisco López Olivo cargó en la nao Nuestra Señora de la Concepción, con destino a México, lo siguiente:

Un barril núm. 26 con:

—I2.5 libras de cenizas azules de pintura a 20 reales, 8500 maravedíes;

-8 libras de esmaltes a 8 reales, 2 I76 maravedíes;

-4 libras de bermellón a io reales, I 360 maravedíes y

provincia de Tierra Firme, entre otros pigmentos, " 5 libras de verde terri a 22 reales, 3740 maravedíes; I. 5 libras de verde granillo a 22 reales, I I 22 maravedíes... " (AGI, Contratación, I097, año I592, núm. 5-I, ff. 222r. y 227r.).

35. AGI, Contratación, I Ioo, año I592-I593, núm. 4-I, f. 23r. y v. 
- 3 almudes de castańas y un barrilillo pequeño de higos que van dentro, 8 reales, 272 maravedíes. ${ }^{36}$

Resulta extraña la gran diferencia de precios que se advierte entre ambos envíos: a cuatro reales la libra en el primero, frente a los io reales en el segundo, más aún cuando ambas partidas se registraron con tan sólo un año de diferencia. Tal variación se explicaría únicamente si el primer bermellón se obtuvo mediante trituración del cinabrio, abundante y fácil de conseguir, mientras que el segundo se habría preparado artificialmente con polvo de mercurio sobre azufre fundido.

En España, durante todo el siglo xvı, las minas de Almadén en Ciudad Real fueron famosas por la producción del llamado "bermellón de Castilla", para diferenciarlo del bermellón artificial.

Los envíos de bermellón al Virreinato del Perú fueron más escasos debido a que era abundante en aquellas tierras, pues la población autóctona lo empleaba desde tiempo inmemorial, como lo hace constar el cronista Joseph de Acosta en su Historia natural y moral de las Indias:

dígolo porque los ingas, reyes del Pirú, y los indios naturales de él, labraron gran tiempo las minas de azogue, sin saber del azogue ni conocelle, ni pretender otra cosa sino este minio o bermellón que ellos llaman Llimpi, el cual preciaban mucho por el mismo efecto que Plinio ha referido [...] que es para pintarse o teñirse con él los rostros y el cuerpo suyos y de sus ídolos. ${ }^{37}$

Un siglo después, Antonio de la Calancha, en su Chronica moralizada del orden de San Agustín en el Perú, con sucesos exemplares vistos en esta Monarchia, publicada en 1638, nos narra el descubrimiento, por los españoles, de las minas de Huancavelica, donde se obtenía en abundancia este metal:

i quiso Dios que en el año 1566 un portugués llamado Henrique Garcés, viendo en manos de un Indio una piedra colorada, que los Indios llaman Llimpi [...], que en Castilla se llama bermellón, que conoció por aver estado en la villa de Almadén en Espańa, que como aquel era el metal del azogue beneficiolo i alló ser lo

36. AGi, Contratación, II I02, año I593, núm. 5-I, f. i i6r.

37. Recogido por Siracusano, op. cit., p. I04. 


\section{JOSÉ MARÍA SÁNCHEZ Y MARÍA DOLORES QUIÑONES}

mesmo, i así se descubrió el cerro de Huancavelica, con cuyo azogue se beneficiaron entonces muchos metales desechados por dismontes. ${ }^{38}$

Estas minas constituyeron un importante yacimiento hasta que definitivamente se agotaron en el siglo XviII.

También se obtenía rojo de la almagre o "tierra roja”, pigmento natural extraído de rocas férricas, aunque podía elaborarse artificialmente mediante calcinación del ocre amarillo. ${ }^{39}$ Empleado desde la prehistoria, entre sus cualidades cabría destacar su gran poder cubriente, su notable estabilidad, su resistencia a la luz y su asequible precio debido a que resultaba fácil obtenerlo.

Su circulación en las flotas se registra desde I596, cuando Lázaro de Arpide apuntó que en la nao Santa María de San Vicente se fletaban con destino a Nueva España "4 libras de almagre a 8 maravedíes, 32 maravedíes". ${ }^{\circ}$

Variante del almagre fue el bol, arcilla rojiza comercializada con las denominaciones "bol arménico", "bol de levante" y "bol de Llanes", este último de procedencia nacional.

Su empleo como pigmento no debió ser muy frecuente pero sí se usó a menudo como base para el dorado en obras de imaginería. Ciertamente, se aplicó mucho más en labores de policromía como última capa del aparejo que fijaba los panes de oro o plata, ya que, por su suavidad, permitía bruñirlos luego. ${ }^{4 \mathrm{I}}$ Esto explicaría las grandes cantidades de él consignadas en los registros. En I592, Antonio Hurtado Salguero, pasajero de la nao Santa Catalina, cargó con destino a la provincia de Tierra Firme "Ioo libras de bol para pintores en 44 reales, I 496 maravedíes". ${ }^{42}$ Igualmente, Juan Bautista Argüello, pasajero de la nao San Antonio de Padua, cargó con destino a la provincia de Nueva España,

\footnotetext{
38. Ibidem, p. 99.

39. En la tratadística se distingue la tierra roja o almagre del ocre quemado u oscuro.

40. AGI, Contratación, i I I 8, año I596, núm. 33-I, f. 26r. y v.

4I. Pacheco comenta este uso: "El bol que se gasta en la Andalucía es más suave y amoroso que el de Castilla. Quiere ser muy bien molido en losa muy limpia y no estar muchos días antes molido y en agua, porque se enflaquece demasiado. La templa para embolar suele ser lo más dificultoso para acertar en el aparejo [...] la primera mano, la cual se da resfregada, si está flaca se ve en que sale muy colorada y no cubre; si fuerte, se pone el bol negro y entonces está en tiempo de poderse remediar añadiendo agua o cola. Algunos echan al bol un poco de lápiz de plomo molido muy bien al agua para hallar suave el bol y que al bruñir corra la piedra sin rozar, pero ha de ser muy poco y, si está bueno el aparejo, puede pasar sin él”.
}

42. AGI, Contratación, I097, año I592, núm. 5-I, ff. 222 r.-227 r. 
"un barril quintaleño no 2 de bol que costó I 2 reales, 408 maravedíes; más otro barril medio quintaleño de bol que costó 6 reales, 204 maravedíes". ${ }^{43}$

A esta misma gama de tonos pertenecía el azarcón, también llamado "minio" o "plomo rojo", pigmento artificial de color anaranjado o rojo obtenido por calcinación del albayalde. ${ }^{44}$ Debido a su bajo costo y fácil adquisición, se usaba para adulterar el bermellón o el carmín, más costosos y apreciados.

Era un pigmento poco estable en cuanto "escupe un sarro con el tiempo que destruye el jugo de lo pintado". Aunque tal inconveniente se atenuaba en los lugares de clima seco, debido a él, a lo largo del siglo XVI, decayó el uso del azarcón como pigmento y se destinó preferentemente a la fabricación de un aceite secante — el aceite graso de azarcón-imprescindible para las lacas y las encarnaciones en la imaginería. ${ }^{45}$

Las cantidades remitidas oscilaron mucho: desde las seis libras que en 1592 consigna Antonio Hurtado Salguero, mercader peruano, con destino al puerto de Nombre de Dios ${ }^{46}$ a las dos arrobas que registra Juan de Bustinza, vecino de Sevilla, en la nao Nuestra Señora del Rosario, dirigidas a la Nueva España. ${ }^{47}$ En todos los casos el precio osciló en torno a un real o uno y medio reales la libra.

Para la técnica del fresco se empleó preferentemente el albín, conocido también como "pavonazo", pigmento mineral obtenido del oligisto o hematita. Se trataba de un óxido de hierro del que se obtenía un color rojo oscuro o pardo violáceo. Pacheco lo define como "un carmín de donde se hacen rosados y morados, mezclados con el esmalte, que es el azul que se mantiene al fresco, por ser de vidrio"..$^{8}$ Verificamos su envío en una sola ocasión, en el registro que Pedro Colbert, vecino de Sevilla, realizó en el navío La Blanca Paloma, con destino a Nueva España en I596: "4 libras de albín a real la libra, I36 maravedíes". ${ }^{4}$

Sin embargo, no hay ningún cargamento del célebre carmín, pigmento de gran calidad entre los más "finos, subidos y caros", cuyo uso se especificaba

43. AGI, Contratación, II32, año I599, núm. 4-I, f. 26 r. y v.

44. Así describe Palomino su obtención: "también se puede hacer minio o azarcón del albayalde, tomando la cantidad que se quisiere y quebrantado meterlo dentro de un botecillo de vidrio bien tapado y embarrarlo con estiércol y tierra de alfarero; y de este modo se pondrá en un horno de vidrio al fuego de reverberio por la noche y, a la mañana, quitarle y dejarle enfriar y se hallará el minio en toda perfección".

45. Bruquetas Galán, Técnicas y materiales..., op. cit., p. I88.

46. AGI, Contratación, I096, año I592, núm. 2, f. 23 r. y v.

47. AGI, Contratación, IIO4, año I592-I593, núm. 7-I, f. I I8.

48. Pacheco, op. cit., p. 456.

49. AGI, Contratación, II23, año I596, núm. 3-I, f. 54r. y v. 
con frecuencia en los contratos de obra. Al ser un pigmento poco cubriente, se empleaba, según Pacheco, sobre fondos de bermellón, recurso que además evitaba su excesivo gasto, ya que su precio era muy alto.

A pesar de su frecuente uso, no hay registros suyos en los cargamentos, pues debía de producirse en América sin tener que importarlo de España. ${ }^{50}$

\section{Pigmentos amarillos}

En la gama de amarillos debemos citar en primer lugar el oropimente, también conocido como "jalde", pigmento de origen mineral — sulfuro de arsénicosumamente venenoso. De color muy luminoso, también se podía oscurecer quemándolo, con lo que se conseguía un tono anaranjado. ${ }^{5 \mathrm{I}}$ Aunque usado ya desde la Antigüedad, tuvo su mayor apogeo durante la Edad Media, cuando se empleaba para decorar las techumbres de madera al temple imitando dorados — su nombre se debe precisamente a su semejanza con el oro. También se empleó al fresco y al óleo.

Fue un pigmento barato, cuyo precio oscilaba en torno a un real y cuarto la libra, y se trasladó en las naves siempre en cantidades muy cuantiosas — por arrobas-, quizá a causa de ese posible uso en la decoración de techos como sustitutos del pan de oro. En I592, Juan Lorenzo cargó en la nao San Juan Bautista, con destino a Nueva España, "2 arrobas de oropimente a 33 reales el arroba, monta 2244 maravedíes". 52

También amarillo era el jenuli, pigmento artificial obtenido por óxido de plomo y estańo, aunque poco se sabe en cuanto a su fabricación. Era un pigmento muy cubriente y de alto poder secante. Su comercialización se produjo siempre en pequeñas cantidades —entre seis y tres libras en cada envío-,

50. En España se nombró con frecuencia el "carmín de Indias”, pigmento muy cotizado obtenido del kermes, insecto "cultivado" en los nopales del que los indios obtenían un potente colorante. Su comercio y exportación, sobre todo desde la Nueva Espańa, constituyeron una de las fuentes de ingresos más importantes de la Corona.

5I. Pacheco señala: "Suelen algunos valerse del jalde u oropimente para los amarillos finos a olio [...] suele oscurecerse con el mismo jalde quemado [...] haciendo los más oscuros con ocre oscuro o sombra y almagre [...] harase naranjado con el mismo jalde quemado o con azarcón de la tierra o con bermellón [...] el jalde no se echa en l'agua: es de mal olor, dañoso a la cabeza y bástale ser venenoso para huir dél” (op. cit., p. 484).

52. AGI, Contratación, IIO2, año I592, núm. 2-I, f. 88r. y v. 
como para satisfacer encargos concretos. En 1596, Pedro Colbert, vecino de la ciudad de Sevilla, registró en el navío La Paloma Blanca, con destino a Nueva España, "seis libras de jenuli amarillo a 4 reales libra, 8I6 maravedíes". ${ }^{3}$ Por último, estaba la ancorça, también conocida como "tierra santa", laca obtenida de la raíz de la gualda. ${ }^{54}$ De bajo poder cubriente y muy transparente, se utilizó en especial para producir veladuras. El citado mercader Lázaro de Arpide la envió en 1596 en la nao Santa María de San Vicente en I596: "4 libras de ancorça a 3 reales la libra, 408 maravedíes; más 2 libras de ancorça a 3 reales, 204 maravedíes". 55

\section{Gama de azules}

Los azules siempre se consideraron colores delicados, como refiere Pacheco con estas palabras: "el color más dificultoso de gastar y [que] a muchos pintores buenos se les muere $[\ldots]$ ha de ser de lindo color, delgado y bien afinado y limpio lo primero que se ha de acabar". ${ }^{56}$

En los registros de mercancías relativos a este color, aparecen varias expresiones distintas: "azul", "azul fino" y "cenizas azules", denominaciones todas que, en el siglo XVI, se vinculan con la azurita.

Ya usado en la Antigüedad por los egipcios, el pigmento se obtenía triturando el mineral y sometiéndolo a lavados con agua y vinagre para eliminar impurezas, y la intensidad de su color dependía de la concentración de azurita. ${ }^{57} \mathrm{Su}$ comercio fue regular y su precio varió entre los 34 y los 54 maravedíes por libra.

También azul era el denominado esmalte, nombrado en los cargamentos "esmalte de vidrio", "esmalte azul para pintores", "cenizas de esmalte" y "esmalte de Flandes". Se trata de un pigmento obtenido por medio de la trituración de vidrio coloreado con óxido de cobalto. Se producía en Murano (Venecia) desde principios del siglo Xv, aunque a partir de I470 Flandes y Alemania (especialmente Sajonia) son ya los principales centros donde se prepara.

53. AGI, Contratación, II 23, año I596, núm. 3-I, f. 54r. y v.

54. Hierba silvestre de tallos ramosos de cuatro a seis decímetros de altura, hojas lanceoladas, flores amarillas en espigas y fruto capsular con semillas pequeñas en forma de riñón. También se podía cultivar para cocer sus ramas y obtener tinte amarillo.

55. AGI, Contratación, i I I8, año I596, núm. 33-I, f. 26r. y v.

56. Pacheco, op. cit., p. 484.

57. Bruquetas Galán, Técnicas y materiales..., op. cit., p. I7I. 
62 JOSÉ MARÍA SÁNCHEZ Y MARÍA DOLORES QUIÑONES

Se utilizó fundamentalmente al fresco, por su resistencia a la acción cáustica de la cal, y al óleo, como veladura, sobre una base azul de cualquier pigmento más barato. Su precio osciló en torno a los 6 reales la libra. Su presencia en las flotas se comprueba en I586, cuando Nicolás de Lambartengo, vecino de Sevilla, envía en la nao Nuestra Señora de la Victoria, con destino a la provincia de Tierra Firme, " 5 libras de esmalte de vidrio a 6 reales la libra, I 020 maravedíes". ${ }^{8}$

No hemos comprobado, sin embargo, en las flotas, la presencia de lapislázuli — gema de la que se obtenía el famoso "azul ultramar"-, color muy valorado tanto por su origen — una piedra semipreciosa— como por sus connotaciones simbólicas y sagradas.

Venecia fue el principal proveedor de lapislázuli en Europa en el siglo xvı y lo importaba de las legendarias minas de Badakshan en Afganistán. Era un pigmento muy estable pero posiblemente no se comercializó debido a su alto precio. ${ }^{59}$

\section{Gama de violetas}

En I592, el doctor Luis de Medina envió en la nao San Pedro a Luis Ortiz, vecino del Nuevo Reino de Granada, lo siguiente:

- 3000 panes de oro a 78 reales el millar, 7990 maravedíes [sic];

— diez libras de violeta a 4 reales y cuartillo, I 445 maravedíes;

—una libra de azul fino por 36 reales, I 445 maravedíes; y

—una libra de bermellón I2 reales, 408 maravedíes". ${ }^{60}$

Posiblemente ese color violeta se refería a la "urchilla", pigmento obtenido de un liquen marino criado en las rocas de los litorales que se usó mucho para "iluminar". Se registra en el comercio marítimo europeo desde la segunda mitad del siglo Xv, cuando en I 477 Juan de Lugo, mercader sevillano, comenta que tiempo atrás había enviado a Mendo de Bonilla, vecino de Ciudad Real, "25 cargas de urchilla para pasar a vender allende los puertos". ${ }^{61}$

58. AGI, Contratación, I084, año I586, núm. 4-I, ff. 46r. y 47r.

59. Tal circunstancia es apuntada así por Pacheco: "El azul, entendemos el de Santo Domingo, no el ultramarino, que ni se usa en España ni tienen los pintores della caudal para usarlo" (Pacheco, op. cit., p. 485).

60. AGI, Contratación, I096, año I592, núm. 2, ff. 21r. y 22v.

6I. "Ciudad Real en la Edad Media. Las actividades económicas", en www.ciudad-real.es/ historia/ccm/edadmedioo3.php 
En el tráfico americano aparece también con su nombre específico en una ocasión cuando Antonio Hurtado Salguero, mercader peruano, embarcó en la nao Santa Catalina, con destino al puerto de Nombre de Dios, dos cajas que contenían, entre otros productos: "2 libras de urchilla a 4 reales, 272 maravedíes". ${ }^{62}$

Quizá su escasa circulación se debió a que se hallaba en América y, por lo tanto, no era necesario importarlo, y, sobre todo, porque en el Nuevo Continente se encontraba el índigo, arbusto del que se obtenía el más bello añil.

\section{Gama de pardos-sombras}

Por último, para los pardos en el siglo xvi se usó la denominada "tierra de sombra", pigmento natural de color castaño verdoso, obtenido de tierras compuestas por óxido de hierro, manganeso y calcio en diversas proporciones. Era famosa la de "tierra de Venecia" — a veces denominada "sombras del Tiziano"— y "la de Levante".

La tierra era un pigmento abundante y barato que podía emplearse en cualquier técnica —en especial en el óleo-, y constituía, además, una base muy estable sobre la cual convenía aplicar los colores restantes. En imaginería se utilizó para matizar las carnaciones y como base mordiente del dorado. Su precio osciló en torno a los dos reales la libra, como se comprueba en el registro de Lionel de Cuadros, vecino de Sevilla, en la nao La Salvadora expedida a la Nueva España: "36 libras y media de sombra pardo y negro a 40 reales el quintal, 442 maravedíes". ${ }^{63}$

Asimismo, a esta gama pertenece el "asfalto", también nombrado "espalto", "betún de Judea" o "lápiz judaico", residuo sólido del petróleo del que se obtenía un color pardo dorado muy bello con que se conseguían excelentes veladuras.

Se preparaba moliéndolo hasta reducirlo a un polvo fino, después se le cocía en aceite de linaza y se le podía añadir trementina para acentuar su brillo, además de algún tipo de secante. Llegaba a Europa procedente del Mar Muerto, por lo que era un pigmento muy caro - a 50 reales la libra, frente a los dos reales de las anteriores sombras. Debido a ello, sólo en una ocasión se remitió a América, posiblemente en respuesta a algún encargo concreto por deseo expreso del comitente, pues para el mercader el riesgo era alto y apenas podía generar

62. AGI, Contratación, I097, año I592, núm. 5-I, ff. 222r. y 227 r.

63. AGI, Contratación, II23, año I597, núm. 2-I, f. 83r. y v. 


\section{JOSÉ MARÍA SÁNCHEZ Y MARÍA DOLORES QUIÑONES}

margen de beneficios. Se trata del registro que, en I592, consignó Antonio Hurtado Salguero respecto a un embarque con destino a Tierra Firme, donde, entre otros materiales, incluyó “I libra de asfalto 50 reales, I 700 maravedíes". ${ }^{64}$

\section{Barnices}

Vistos ya los pigmentos, hay que comentar ahora que el proceso de elaboración de una pintura terminaba - al menos durante todo el periodo de la Modernidad - con una capa superficial de barniz aplicada para cumplir una doble función: una estética, al dotar de luminosidad y brillo a la superficie de la obra o al producir "veladuras", efecto plástico muy apreciado por los clientes del momento, y otra funcional, al actuar como un "cristal" que protegía la película pictórica y podía renovarse en cualquier momento, cuando se ensuciase o deteriorase. ${ }^{65}$

El barniz más común en el siglo xvi fue el elaborado con sandáraca o grasilla (goma o resina del enebro), diluida en aceite de linaza. Hasta nueve recetas ofrece Pacheco para fabricar barnices, y una de ellas es la siguiente:

Tomando media libra de aceite de linaza en una olla vidriada y poniéndolo a cocer sobre brasas bien encendidas de carbón, estando bien caliente, se le echen tres cabezas de ajos mondados, que cuezan con él y, en estando dorados, sacarlos fuera y meter una pluma de gallina para ver si está cocido y, en saliendo quemada, echalle cuatro onzas de grasa molida en polvo, que es la goma del enebro (que los árabes llaman sandaraca), y cueza [...] y si quisiese hacerse mejor, puede ser el aceite de espliego sin echarle ajos. ${ }^{66}$

A América se mandaron barnices elaborados: en I594, Andrés Toribio embarcó en el navío Nuestra Señora del Rosario, con destino a la Nueva España, "ítem, un barril quintaleńo con 2.5 arrobas de barniz a 6 ducados el arroba, [que] monta 5610 maravedíes", ${ }^{67}$ aunque también se remitieron las gomas y resi-

64. AGI, Contratación, I097, año I592, núm. 5-I, ff. 222r. y 227 r.

65. En un principio, los barnices eran muy espesos y amarilleaban, lo cual, unido a su tendencia a craquelarse — resquebrajarse — obligaba a renovarlos periódicamente; más tarde se fueron refinando hasta ser más duraderos.

66. Pacheco, op. cit., p. 502.

67. AGI, Contratación, II Io, año I594, núm. I4-I, f. 38r. y v. 
nas (benjuí, trementina, grasa-grasilla o sandáraca, goma arábiga, almáciga...) y sales minerales (almojatre, alcaparrosa o caparrosa, alumbre...) necesarias para producirlos.

Para finalizar, sólo comentaremos que tanto en Espańa como en América, durante los siglos XVI-XVIII, la mayoría de esos productos se vendieron en tiendas de especierías y en boticas, también en virtud de las propiedades curativas que todos ellos poseían.

Las propiedades sanadoras de los colores y otras sustancias ligadas a la "cocina" de la pintura las trataron desde la Antigüedad clásica autores como Hipócrates, Dioscórides, Teofrasto y Galeno, entre otros, cuyas ideas tuvieron continuidad en textos medievales y renacentistas.

En los inventarios de las boticas españolas del siglo XvI ${ }^{68}$ fueron frecuentes pigmentos como el bermellón-cinabrio — de gran utilidad para combatir las bubas—, el almagre —usado para cortar las hemorragias—, el cardenillo —útil "para curar ulceraciones, llagas i cicatrices" - el verdigrís —eficaz para limpiar las llagas, especialmente las de la boca—, el lapislázuli —conveniente "para purgar los humores melancólicos”-, la esmeralda — buena para contrarrestar la epilepsia y acelerar los partos- y el oropimente — que, pese a ser venenoso, puesto sobre el corazón en un paño de lino, preservaba contra la peste. Propiedades similares poseían las esencias y aceites usados como aglutinantes y barnices, como la sandáraca-grasilla — provechosa como calmante y eficaz contra las almorranas. ${ }^{69}$

En ese sentido, con frecuencia los envíos de tales productos a América no se dirigieron a pintores, sino a mercaderes o boticarios, y se hallaban en los mismos cajones donde se almacenaban aceites medicinales y aromáticos, alcoholes, pomadas, ungüentos y emplastos, entre otros. Así se verifica en el envío que Juan de Ábrego, vecino de Sevilla, realizó a Nueva España en I590:

Cajón de medicinas núm. ıо:

—aceite de aparicio, media arroba a 6 reales, 2550 maravedíes;

—aceite amargo, 2 botijas, I arroba a I.5 reales la libra, I 275 maravedíes;

—aceite de ajonjolí, I2 libras a 2 reales, 8I6 maravedíes;

68. Véase Silvia María Pérez González, "Una botica sevillana del primer tercio del siglo XvI", Hiades. Revista de Historia de la Enfermería, núm. 9, 2004, pp. 353-369.

69. Una información más extensa y detallada al respecto se encuentra en Siracusano, "Medezinas buenas de todas las colores", en op. cit., cap. IV, pp. 217-261. 
DOI: http://dx.doi.org/10.22201/iie.18703062e.2009.95.2293

66 JOSÉ MARÍA SÁNCHEZ Y MARÍA DOLORES QUIÑONES

-aceite de almendras dulce, I2 libras a 2 reales, 8I6 maravedíes;

- trementina, media arroba a 24 maravedíes, 306 maravedíes;

-aceite de agripa, 8 libras a 2 reales, 544 maravedíes;

—ungüento de la condesa, 8 libras a 3 reales, 8 I 6 maravedíes;

—ungüento populón, 8 libras a 3 reales, 8I6 maravedíes;

—conserva violada, 8 libras a 3 reales, 816 maravedíes. ${ }^{70}$

Ciertamente, en todas estas sustancias se reconocieron virtudes curativas en un doble ámbito: en el material, porque aliviaban el cuerpo en la forma de enjuagues, pomadas o emplastos, y en el espiritual, porque confortaban el alma al recrear imágenes sagradas que actuaban como guías de salvación. \$

70. AGI, Contratación, I09I, año I590, núm. 4-I, ff. 34r. y 35r. 
DOI: http://dx.doi.org/10.22201/iie.18703062e.2009.95.2293

MATERIALES PICTÓRICOS ENVIADOS A AMÉRICA

Tabla de precios de los materiales pictóricos remitidos a América en el siglo $X V I$

\begin{tabular}{|c|c|c|}
\hline Pigmento & Año & Precio (maravedies por libra) \\
\hline Aceite de linaza & 1594 & 34 \\
\hline Albayalde & 1596 & 45 \\
\hline Albín & 1596 & 34 \\
\hline Almagre & 1596 & 8 \\
\hline Ancorza & 1596 & 102 \\
\hline Azarcón & 1592 & $5 \mathrm{I}$ \\
\hline Azul & 1592 & I 156 \\
\hline Barniz & 1593 & 204 \\
\hline Bermellón & 1596 & 204 \\
\hline Bol & 1597 & 15 \\
\hline Cardenillo & 1594 & 238 \\
\hline Carmín de Brasil & 1592 & 102 \\
\hline Cenizas azules & 1592 & $34 / 54$ \\
\hline Esmalte & 1592 & 272 \\
\hline Espalto & 1592 & I 700 \\
\hline Jenuli & 1596 & 102 \\
\hline Lápiz & 1596 & 68 \\
\hline Oropimente & 1593 & 50 \\
\hline Sombra del Tiziano & 1592 & 102 \\
\hline Sombra negra del Tiziano & 1592 & 170 \\
\hline Sombra parda & 1596 & 102 \\
\hline Sombra negra & 1596 & 68 \\
\hline Urchilla & 1592 & 170 \\
\hline Verde granillo & 1592 & 748 \\
\hline Verde terre & 1592 & 748 \\
\hline
\end{tabular}

